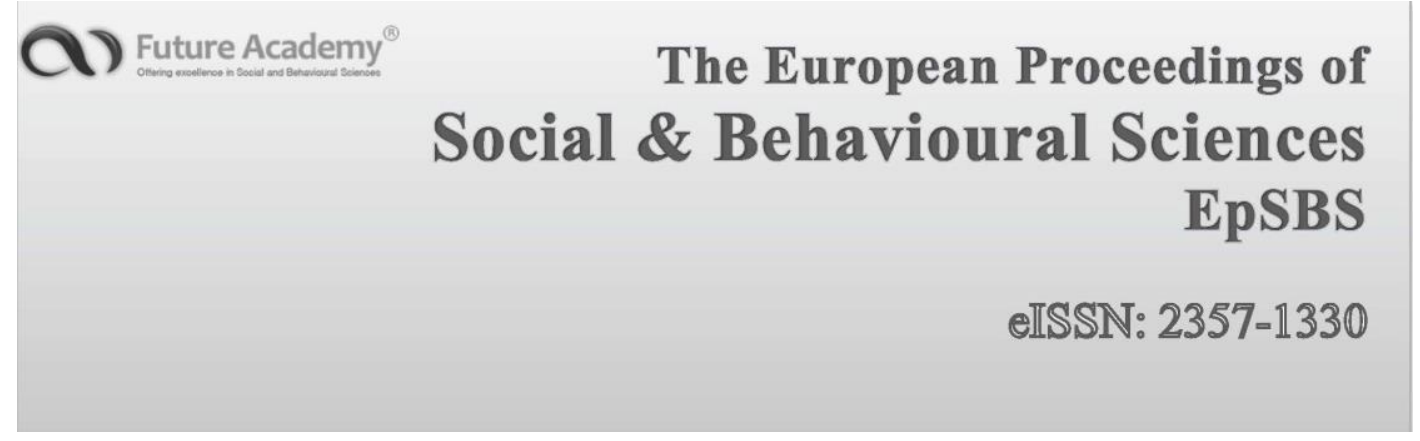

7th International Conference on Education and Educational Psychology (ICEEPSY)

\title{
Traditional Toys and Student Motivation and Commitment in Technological Education
}

\author{
Ana Paula Cardoso ${ }^{\mathrm{a} *}$, Luísa Correia $^{\mathrm{b}}$, Paula Rodrigues ${ }^{\mathrm{c}}$, Sara Felizardo $^{\mathrm{d}}$, Ana \\ Lopes $^{\mathrm{e}}$ \\ * Corresponding author: Ana Paula Cardoso

\begin{abstract}
${ }^{a}$ Instituto Politécnico de Viseu, CI\&DETS, Escola Superior de Educação, Portugal, a.p.cardoso@esev.ipv.pt
${ }^{b}$ Agrupamento de Escolas de Águeda Sul, Águeda, Portugal, luisamgcorreia@hotmail.com

${ }^{c}$ Instituto Politécnico de Viseu, CI\&DETS, Escola Superior de Educação, Portugal, pr@esev.ipv.pt ${ }^{d}$ Instituto Politécnico de Viseu, CI\&DETS, Escola Superior de Educação, Portugal, sfelizardo@esev.ipv.pt

${ }^{e}$ Instituto Politécnico de Viseu, CI\&DETS, Escola Superior de Educação, Portugal, anacostalopes@esev.ipv.pt
\end{abstract}

\begin{abstract}
Technological Education is a subject where students acquire knowledge and technical skills, which will enable them to analyse and resolve specific situations and will prepare them for an increasingly technological world. This course requires students to gain knowledge and know-how such that motivation and commitment are crucial for the development of classroom projects and activities. It is in this context that traditional toys come up in this study as catalysts for motivation and student interest. Thus, the aim of the research performed is to understand whether the units of work related to traditional toys promote the students' motivation and commitment on Technological Education. In terms of methodology, we carried out an exploratory research of qualitative nature, based on semistructured interviews with teachers and students in the 2nd cycle of basic education at five schools in the municipality of Viseu, Portugal. Nine teachers and forty-five Technological Education students, aged between 10 and 12 years, attending the 5th and 6th years of schooling participated. Content analysis of the answers revealed that the implementation of units of work involving the construction of traditional toys are conducive to students' motivation and commitment, constituting an added value in Technological Education. As this is a classroom project, it allows students to apply technical knowledge they have acquired. Thus, starting from a first idea, it allows them to experience all of the stages of toy building, from conception to completion, contributing to greater student satisfaction in the teaching-learning process.
\end{abstract}

(C) 2016 Published by Future Academy www.FutureAcademy.org.uk

Keywords: Traditional toys; motivation; commitment; Technological Education; basic education 


\section{Introduction}

Technological Education holds a specific place in the curricula and educational activities of Portuguese basic education, due to its potential for developing, on the part of students, the know-how, which is essential to being, a necessary requisite in a balanced society (Porfírio, 1992). This school subject focuses on two major areas: "technics and science": technics uses science in its application and science constantly uses the results of technics, both contributing to a technological culture (Ministério da Educação, 2001).

This subject develops fundamental skills towards an adaptation to an increasingly technological world. It comprises a strong practical component, developing attitudes such as job satisfaction, a sense of responsibility and the ability to work well within a group. As this practice is based on the elaboration and implementation of projects, we are faced with a set of activities that promote the development of sensitivity, of critical and creative thinking, being a key subject for shaping the individual in his/her entirety, i.e., at the affective, cognitive and social level (Porfírio, 1992).

Therefore, it becomes clear that Technological Education requires from students a knowledge and know-how within which motivation and commitment are crucial to the development of projects and activities likely to enhance learning.

The term motivation comes from the Latin word "movere" which means moving. This concept automatically evokes the one of activity (Drew, Olds, \& Olds, 2007). Motivation is the most important factor why someone performs a task, namely, it is the cause that leads the person to do it, it is what sets the task in motion, towards the end one wants to achieve.

For Fontaine (2005), motivation is the dynamic side of the action, in other words, that which explains the direction and persistence of the individual's behavior in pursuit of one's objectives and goals meant to be achieved. The term commitment, on the other hand, refers to the act of doing something with dedication, or a lot of concentration, i.e., the individual who is committed is intent, dedicated to the task he/she wants to perform (Oliveira, 2008).

From the didactic point of view, motivating implies creating situations that make students feel motivated and want to learn. Self-determination theory considers humans to be actively seeking optimal challenges and new experiences to master and integrate (Decy \& Ryan, 1985; Ryan \& Deci, 2000). Thus, in the promotion of motivation the needs of the student ought to be taken into account, once motivation is the cause that drives the action, the strength and nature of the effort that enables the learner to achieve the intended objectives (Oliveira, 2008).

In this sense, motivation is crucial for the development of any activity with quality, satisfaction and success, and is the main factor influencing student behavior, allowing for greater or lesser commitment in the fulfilment of learning-related activities (Carita, Silva, Monteiro, \& Diniz, 2001). In turn, motivation, commitment and learning are closely linked, maintaining a reciprocal relationship. Motivation influences commitment and learning while learning fosters motivation and commitment.

Motivation and commitment should not be considered apart from the context in which they are originated, as the student's motivation lies in the interaction with the world of people and things around him/her (Drew et al., 2007). Hence, the key role the teacher plays at this level in terms of the pedagogical interaction inside the classroom. 
The teacher should therefore be a facilitator of student motivation and commitment, providing educational environments rich in varied experiences, likely to potentiate the development of skills through active student participation (Knüppe, 2006).

Within a cognitive and collaborative learning approach, Bruner $(1996,2006)$ argues that if the teacher promotes interest and curiosity about the contents, if she/he enhances their ability to seek, to find, if he/she talks to the students in a way that is suitable in view of their stage of development, i.e., if the teaching method is well-designed and external stimuli are relied upon, students will feel motivated and involved in the teaching-learning process.

According to Drew et al. (2007), the teacher should make education as real as possible, showing students the immediate usefulness of the contents presented by relating them to professional, technical, industrial applicability and to students' own interest, according to their experiences and the reality around them. In this way, lessons will become authentic, and students will apply their motivation in learning whenever both they and the teachers are able to create favorable conditions for the exploration of the contents to be learned.

In this regard, traditional toys are educational applications in which the entertainment component is combined with and favors learning, as it promotes individual understanding of the world, through the situations of daily life, observation, research, critical sense (through the questions and answers), freedom, security, conflict resolution, understanding the differences and ability to face and solve problems (Drew et al., 2007).

In this sense, we consider that teaching practices based on the construction of traditional toys can be used to teach content through methodological proposals based on the interests of the students, likely to engage them in school activities. From this framework, we formulated the problem of this research:

- Do the work units related to traditional games and toys promote motivation and commitment on the part of students in the school subject Technological Education?

To respond to the question stated, goals were outlined, which were set as guidelines, namely:

- inquire about the perspective that teachers have of motivation and commitment;

- know the strategies that teachers use to promote motivation and commitment on the part of students;

- perceive, through the opinion of teachers, if the games and traditional toys may be factors which foster motivation and commitment with regard to the subject Technological Education;

- check motivation and commitment of students with regard to the subject Technological Education;

- ascertain that students feel motivated and committed in carrying out activities related to traditional toys.

\section{Methodology}

\subsection{Research design}

In the present research, we developed an exploratory study of a qualitative nature (Bogdan \& Biklen, 1994), in which the direct source of data is the natural environment and the investigator the main tool for data collection. The "hypotheses" have emerged throughout the investigation, such as the 
information and data. The meaning is of outstanding importance in this context and the researcher seeks to understand phenomena from the perspective of the participants in the study.

According to Carmo and Ferreira (1998), research is naturalistic because it develops in a natural context, the event site, to try to understand the existing phenomena; it is inductive, once it develops concepts and understands phenomena by relying on the patterns arising from the data collection; it is descriptive, because the data obtained are varied, rich and detailed, as they were obtained within the field of action, all being strictly transcribed.

\subsection{Participants}

The study comprised as participants nine teachers of Technological Education of the 2nd cycle of basic education and a total of forty-five students, corresponding to five students per teacher, from five schools in the municipality of Viseu (Portugal).

Technological Education teachers are mostly male (6), only three being women. They have some professional experience, with the same number of teachers (4) who have taught between 21 to 30 years and between 31 to 40 . Only one of the teachers has been in the profession for no more than ten years.

Teachers have different academic qualifications: five of them hold a bachelor's degree, two a master's degree and two a diploma. Their initial training is diverse: Visual and Technological Education (4) Visual Education (2) Technological Education (1) Agricultural Engineering (1) and Timber Engineering (1).

Students are distributed evenly by gender and are aged between 10 and 12, with most being 11 (21 students). They attend the 5 th grade (30 students) and the 6 th (15 students).

\subsection{Data collection tools}

Given the qualitative nature of the study, we used semi-structured interviews to collect data (Ghiglione \& Matalon, 2001). The choice of this interview mode has to do with the possibility of comparing the answers of respondents, since subjects are asked to answer the same questions and, simultaneously, it allows also for a high degree of flexibility in the exploration of issues.

Interviews were organized according to a given outline and held in an informal atmosphere, always allowing respondents to answer openly and thus freely present their views.

The interviews with teachers were held in the library of basic schools, after work hours, and took place in a pleasant atmosphere. The average interview time was 45 minutes with a duration ranging from 60 minutes for the longest, and 30 minutes for the shortest.

The interviews to students took place during school hours assigned to the school subject Technological Education. The students showed great interest in their fulfilment, participated autonomously, answering questions, awaiting their turn with great attention and sympathy.

\subsection{Procedure}

For the purposes of monitoring the application of the interviews within a school context, permission was asked to the General Directorate of Education (DGE), and this request was promptly granted as 
follows: "the request for investigation within a school context is allowed, considering that, as subject to analysis, the requirements are met".

After receiving the response from the DGE, we visited the schools, we presented the study to the respective directors and requested the authorization for the collaboration of teachers in the interviews. In the requests made, anonymity of institutions and participants was guaranteed and also access to the results of the study was provided.

Next, parents and guardians were sent a request to enable participation of their children in the interviews. Subsequently, interviews were conducted in the usual context of the stakeholders in order not to influence the responses given.

\subsection{Data analysis}

Content analysis was the technique used to process the collected data. According to Bardin (1995), it comprises a set of steps that allow through systematic procedures and objectives, for an analysis of the information gathered in a data collection tool in order to obtain quantitative or qualitative indicators, which will enable the attainment of inferences pertaining to the objectives outlined in a study.

In order to guarantee high objectivity, we undertook the analysis of the information collected systematically and organized through categorization. Firstly, we made a pre-analysis and, for that purpose, organized the data from the interview transcript. Then, we proceeded to the categorization and for that effect, we referenced the categories and subcategories from the corresponding thematic blocks corresponding to the various questions of the interview scripts.

\section{Results and discussion}

\subsection{Data relating to teachers}

\subsubsection{Definition of motivation and commitment}

In the first dimension, "definition of motivation and commitment", we posed three questions: "Which behaviors, on the part of your students, do you consider to be revealing of their motivation?"; "Which behaviors, on the part of your students, do you consider to be revealing of their commitment?"; "What is your opinion on the motivation and commitment of students concerning the school subject Technological Education?".

Taking into account the responses of teachers, we can say that motivation is evidenced by the application/know-how (8 references), participation and presentation of ideas revealed by students (5). In turn, the commitment appears associated to interest/wanting to know (5), practical application and appreciation of the final result (3).

Combined analysis of the data reveals that they are two closely related factors, there being behaviors which are said to reveal motivation and also commitment (the practical application and interest). They are very important because of the practical nature of the school subject (5), considered to be two factors that "go hand in hand" (4), because students need to feel motivated to engage. 
These results are in line with the perspective of Knüppe (2006), who states that motivation is a requirement, a prerequisite of learning, as it has direct implications for the quality of involvement in school tasks.

\subsubsection{Promotional strategies of motivation and commitment}

In the second dimension, "promotional strategies of motivation and commitment", the question was raised: "How do you promote motivation and commitment on the part of your students?".

We considered three categories to group the responses of teachers: the first has to do with the teacher's profile and emphasizes dialogue (3), the appreciation of working capacity (2), the positive reinforcements (2) and what the teacher is like and the way he/she conducts him/herself (1); the second relates to the methodology used and covers more than half of the indicators that are expressed, in which research and application of the problem-solving method are highlighted (7), the identification of situations/problems related to the daily life of students (4), experimentation (3), discovery (3) and the fulfilment of group work (2); and the third relates to the use of a variety of teaching resources (6), namely audiovisual display, didactic games, etc.

Through combined analysis of the responses we consider that the strategies promoting motivation and commitment have to do, firstly, with the methodology used by the teacher, with special emphasis on the application of the problem-solving method and the identification of problem situations related to students' daily life. This is in line with the perspective of Porfírio (1992), who states that the application of this method has many advantages in the teaching-learning process, enhancing the active participation of students and learning by discovery.

The use of diversified and appealing didactic resources is also considered important to encourage motivation and commitment of students. In this regard, as Bruner (1996, 2006) argues, if the methodology used is appropriate and if the external stimuli are present, students will feel motivated for the teaching-learning process.

\subsubsection{Factors of motivation and commitment}

In the third dimension, "factors of motivation and commitment", we placed two questions: "This school year, have you developed work units related to the traditional toy?"; "In your opinion, how can the performance of activities involving the construction of toys promote the motivation and commitment of the students?".

Except for two teachers, all the others report having developed work units related to the traditional toys. The construction of the weathervane (6), works in textile wood and ceramics: animals, transport vehicles, dolls (3), as well as the realization of decorative elements depicting Christmas (2) were the most highlighted activities.

In the perspective of the teachers surveyed, the completion of a simple object (8) is a very important factor for the promotion of motivation and commitment of the students. Also highlighted is the application of knowledge (6), student involvement from the conception of the object to its completion (4), the affective link of the student to the object created by him/her (2), as well as the playful nature that comes along with the concretion of the toy (2). 
These results underline how important it is for the teacher to promote a kind of teaching which is as real as possible, showing the usefulness of the contents addressed, relating them to technical applications and of interest for the students themselves (Drew et al., 2007).

\subsection{Data relating to students}

\subsubsection{Motivation and commitment for the school subject Technological Education}

In the first dimension, "motivation and commitment for the school subject Technological Education" we put the following questions: "Which were the works that you did this school year in the subject Technological Education"; "Which did you like most?"; "What were the difficulties you felt?".

In the first category the following activities, developed by the students throughout the year are mentioned: the development of the cover (32), history of metals/object (25), weathervane (20), cubes/cardboard box (18), recreation of a work of art (9), Christmas figures (5), logo (5), hydraulic wheel (5) and building a house (5).

Within the second category, the favorite activities of students are revealed: the fan and the weathervane (15), the cover (13), recreating a work of art (6) and the box (5).

Within the third category, "the difficulties experienced by students in Technological Education classes" mentioned in the first place were, the difficulty of measuring (17), the lack of creativity (7), difficulty in pasting (6), cutting (5) and drawing (3).

Combined analysis of the responses allows us to conclude that most students did similar activities, despite belonging to different institutions. Regarding students' favorite activities, it was found that they prefer activities related to games and toys, for, in classes where these activities were done, the construction of the weathervane was one of the activities they most enjoyed performing.

Analyzing these results, one deduces that the construction of toys involves several work stages, which allow students to be creative and exercise their technical skills. Given the appreciation, persistence and attention they have shown and the way they overcame the difficulties, one concludes that the fulfilment of activities relating to traditional toys are a practice to be followed in the subject Technological Education, so that students may overcome these lacunae.

\subsubsection{The construction of the traditional toy and the commitment and motivation of students}

In the second dimension, "construction of the traditional toy and the commitment and motivation of students", a few questions were placed: "Did you, along this school year, develop work units, related to traditional games and toys?"; "If so, what were they?"; "Did you enjoy performing them? Why?".

Taking into account the students' responses, three categories were created: the first concerns the activities undertaken, the second, the type of contributions and the third the comparison with other work units.

The students who responded report that they carried out activities related to games and traditional toys namely the construction of the fan/weathercock (20); of cardboard boxes (18); of Christmas figures: bells, stars, strollers (5); of the hydraulic wheel (5), of a house (5) and working with tubes (4).

Regarding the type of contributions that the activities related to the construction of traditional toys offer, the following indicators ought to be highlighted: the appreciation for the theme (10), the fact that 
they consider that the construction is more cute (9), due to the materials (8) and the fact that it is interesting that they make their own toys (4) (see Table 1).

Table 1. Contributions from participation in traditional toys construction activities.

\begin{tabular}{|c|c|c|c|}
\hline Dimension & Category & Indicators & $\mathrm{N}$ \\
\hline \multirow{7}{*}{$\begin{array}{l}\text { The construction of the } \\
\text { traditional toy and } \\
\text { commitment and } \\
\text { motivation on the part } \\
\text { of students }\end{array}$} & \multirow[t]{7}{*}{ Kind of contributions } & Appreciation for the theme & 10 \\
\hline & & The construction is more cute & 9 \\
\hline & & In the end we can use it/them & 2 \\
\hline & & It is interesting to make our own toys & 4 \\
\hline & & Due to the materials & 8 \\
\hline & & It's great fun working in groups & 2 \\
\hline & & At the end our work will be seen & 2 \\
\hline Total & & & 37 \\
\hline
\end{tabular}

Comparing the work units involving the construction of traditional toys with other units, a reasonable number of students (20 references, corresponding to $44.4 \%$ ) consider that they are more interesting than others. It is also highlighted by the students that it's fun they are the ones who get to build the toys (11 references, corresponding to $24.4 \%$ ), that they like to experiment (10 references, corresponding to $22.2 \%$ ), that, at the end students can play with them ( 7 references, corresponding to $15.5 \%$ ), that these activities are easier than others (4 references, corresponding to $8.8 \%$ ) and that they work through play (3 references, equivalent to 6.6\%) (see Table 2).

The overall analysis of the data having been undertaken, we can say that thirty-five (out of the fortyfive) students $(77.8 \%)$ undertook traditional activities related to the construction of traditional toys and those who did not perform those activities expressed they'd like to try.

In the view of the students who responded, the fulfilment of activities which involve the construction of traditional toys enhances appreciation for the theme, they feel more motivated, they like the materials, they find ideas in the environment around them and through book search, they consider building more fun, and they feel committed because they are themselves building.

In turn, comparing these work units with other units, one observes that students are more interested in those involving the construction of the toy. The circumstance that they don't need to buy the toy, that it is different, that they have fun building it, that they can play in the end, see if it works and have the chance to display the toys were some of the aspects highlighted by the students, unlike the units in which "the activities are always the same, they are no longer fun, and besides, toys were bought".

It was also referred in a more detailed way: "I prefer the toy because I can learn so as to invent other forms with other materials"; "at the time of our parents and grandparents there were no toys, they had to invent them, it was interesting"; "the toy is something that everyone wants, it is better than the other activities"; "we have more freedom, we work in group, we seldom do it and it's easier than geometry".

The combined analysis of the data reveals that the performance of work units involving the construction of games and traditional toys are conducive to motivation and commitment on the part of the students. Moreover, the fact that students consider it "easier" to build these traditional activities, 
leads us to admit that their implementation is a good choice for the success of learning in this school subject.

Table 2. Comparison of the work unit "games and traditional toys" with other Technological Education work units.

\begin{tabular}{|c|c|c|c|}
\hline Dimension & Category & Indicators & $\mathrm{N}$ \\
\hline \multirow{6}{*}{$\begin{array}{l}\text { The construction of the } \\
\text { traditional toy and } \\
\text { commitment and } \\
\text { motivation on the part } \\
\text { of students }\end{array}$} & \multirow{6}{*}{$\begin{array}{l}\text { Comparison with } \\
\text { other work units }\end{array}$} & I like to experiment & 10 \\
\hline & & They are more interesting than the others & 20 \\
\hline & & We work through play & 3 \\
\hline & & They are easier than the others & 4 \\
\hline & & It's fun that we're the ones to build toys & 11 \\
\hline & & At the end we can play with the toys & 7 \\
\hline Total & & & 55 \\
\hline
\end{tabular}

\section{Conclusion}

The empirical study undertaken has enabled us to realize that teachers and students involved with the school subject Technological Education consider the construction of traditional toys, in the classroom, an important contribution to the motivation and commitment of students.

In the perspective of teachers, motivation and commitment are considered two very important aspects due to the practical nature of the subject and should therefore be encouraged in teaching practices.

The school subject Technological Education requires from students a diversity of knowledge and know-how, which involves the construction of ideas, creativity, understanding, experimenting, problem-solving, where motivation and commitment are essential.

In order that there is motivation and commitment, it is necessary for the teacher to use certain strategies of a methodological nature, specifically research and the application of the method of problem-solving. These results are in line with the perspective of Porfírio (1992) who advocates the use of this method in the subject Technological Education as structuring element of the teaching and learning strategies, as it allows for an increase of student participation in this process.

Also the identification of situations/problems related to the daily life of students is, in the teachers' perspective, very important for the promotion of motivation and commitment, as it stimulates interest in schoolwork. Despite the importance of technologies in today's world, traditional toys can be a pedagogical asset as concerns the age group of the students who attend the subject Technological Education.

Worth noticing is the fact that the construction of traditional toys in the classroom is a factor of motivation and commitment on the part of students, for the realization of objects that they consider simple, the emotional connection they create for the toy conceived by them and the playful surrounding environment are promoted so.

It follows, therefore, that the methodology of the subject, on its own right, is a strategy to promote students' motivation and commitment and, when combined with the construction of games and toys, it 
is a valuable factor of motivation and commitment in the process of teaching-learning the subject Technological Education.

Regarding the perspective of students, we can conclude that the performance of activities involving the construction of traditional toys promotes their motivation and commitment, confirming the perspective of the teachers in this regard.

The fulfilment of the activities which involve the construction of traditional toys helps to overcome the difficulties inherent to the subject. Like the teachers, students ascribe these aspects to the theme itself, its playful character and the fact that it is they who build the toys and can use what they have built. These activities also enhance the application of knowledge, according to the scheme "design/make/use", once students agree to the construction of objects which, to begin with, seem simple, they enjoy the fact that it is they who conceive the objects and see the final result.

We also acknowledged that students who undertook the construction of games and toys in the classroom proved to be highly motivated and those who did not showed interest in participating in similar projects.

In short, through the perspectives of teachers and students, we understood the nature of completeness which involves performing a unit of work on traditional toys, and so its fulfilment is a very important contribution to the promotion of motivation and commitment on the part of students attending the subject Technological Education.

\section{Acknowledgements}

The Portuguese Foundation for Science and Technology (FCT), and the Center for Studies in Education, Technologies and Health (CI\&DETS) of the Polytechnic Institute of Viseu.

\section{References}

Bardin, L. (1995). Análise de conteúdo. Lisboa: Edições 70

Bogdan, R., \& Biklen, S. (1994). Investigação qualitativa em Educação. Porto: Porto Editora.

Bruner, J. (1996). A cultura da educação. Cambridge, MA: Harvard University Press.

Bruner, J. (2006). In search of Pedagogy: The selected works of Jerome S. Bruner. London, UK: Taylor \& Francis, Lta.

Carita, A., Silva, A. C., Monteiro, A. F., \& Diniz, T. P. (2001). Como ensinar a estudar. Lisboa: Editorial Presença.

Carmo, H., \& Ferreira, M. M. (1998). Metodologia da investigação: Guia para auto-aprendizagem. Lisboa: Universidade Aberta.

Deci, E. L., \& Ryan, R. M. (1985). Intrinsic motivation and self-determination in human behaviour. New York: Plenum.

Drew, W., Olds, A., \& Olds, H. (2007). Como motivar os seus alunos. Lisboa: Plátano Editora.

Fontaine, A. M. (2005). Motivação em contexto escolar. Lisboa: Universidade Aberta.

Ghiglione, R., \& Matalon, B. (2001). O inquérito: Teoria e prática (4a ed.). Lisboa: Celta Editora.

Knüppe, L. (2006). Motivação e desmotivação: Desafio para as professoras do ensino fundamental. Educar em Revista Curitiba, 27, 277-290.

Ministério da Educação (2001). Educação Tecnológica, $3^{\circ}$ Ciclo do EB: Programas do $7^{o}$ e $8^{o}$ anos. Lisboa: Ministério da Educação.

Oliveira, J. E. (2008). A motivação ética no processo de ensino/aprendizagem na formação de professores do ensino fundamental (Tese de Mestrado). Universidade Federal do Rio de Janeiro, Rio de Janeiro.

Porfírio, M. (1992). Metodologia do projeto tecnológico. Lisboa: Universidade Aberta.

Ryan, R. M., \& Deci, E. (2000). Self-determination theory and the facilitation of intrinsic motivation, social development, and well-being. American Psychologist, 55(1), 68-78. 